\title{
ANALISIS PENERAPAN PEMBIAYAAN AKAD MURABAHAH BANK RAKYAT INDONESIA SYARIAH (BRI SYARIAH) PEKANBARU
}

\author{
Mohd Winario ${ }^{1}$ \\ Sekolah Tinggi Ekonomi Islam Iqra Annisa Pekanbaru \\ e-mail: mohd.winario@stei-iqra-annisa.ac.id \\ Irawati ${ }^{2}$ \\ Universitas Islam Negeri Sultan Syarif Kasim Riau \\ e-mail: irasofyanpku@gmail.com \\ Hasgimianti $^{3}$ \\ Universitas Islam Negeri Sultan Syarif Kasim Riau \\ e-mail: hasgimianti@uin-suska.ac.id \\ Emilia Susanti ${ }^{4}$ \\ Universitas Islam Negeri Sultan Syarif Kasim Riau \\ e-mail: Emilia.susanti067@gmail.com
}

\begin{abstract}
Abstrak
Penelitian ini dilaksanakan di BRI Syariah Pekanbaru, dengan tujuan mengetahui penerapan pembiayaan akad murabahah apakah sesuai dengan prinsip-prinsip Islam juga apakah sudah sesuai dengan fatwa yang telah ditetapkan oleh DSN-MUI. Metode pengambilan sampel penelitian ini dengan menggunakan snowball sampling, dengan cara interview, observasi dan dokumentasi. Penelitian ini menggunakan analisis deskriptif kualitatif. Hasil penelitian ini dapat disimpulkan bahwa penerapan pembiayaan murabahah BRI Syariah Pekanbaru menggunakan sistem persentase berjenjang dari tiap tahunnya dari pokok pembiayaan murabahahnya. Penentuan margin masih memperhitungkan berdasarkan BI Rate dan melihat margin yang berlaku di Bank lain. Sistem pelaksanaan pembiayaan murabahah pada bank bisa mulai dari syarat administrasi, syarat jaminan, syarat pembiayaan, plafond pembiayaan, jangka waktu pembiayaan, dan biaya yang dibebankan kepada nasabah. Dalam penetapan margin pembiayaan murabahah masih menggunakan tingkat inflasi per-tahunnya. Semakin tinggi BI rate, maka semakin tinggi pula margin yang diambil oleh bank dari nasabahnya.
\end{abstract}

Kata Kunci: Bank Syariah, Pembiayaan, Akad, Murabahah.

\begin{abstract}
This research was conducted at BRI Syariah Pekanbaru, with the aim of knowing the application of murabahah financing, is it in accordance with Islamic principles or is it in accordance with the fatwa set by DSN-MUI. The sampling method of this research using snowball sampling, by interview, observation and documentation. This research uses descriptive qualitative analysis. The results can be concluded that the application of BRI Syariah Pekanbaru murabaha financing uses a tiered percentage system from each year on the principal of murabahah financing. Determination of margins is still calculated based on the BI Rate and looking at the applicable margins in other banks. The murabahah financing system at the bank can start from administrative requirements, collateral requirements, financing conditions, financing ceiling, financing period, and fees charged to customers. In determining murabahah financing margins, the rate of inflation is still used annually. If the BI rate is higher, then the margin taken by the bank of the customers will be higher also.
\end{abstract}

Keywords: Islamic Bank, Financing, Contract, Murabahah. 


\section{PENDAHULUAN}

Salah satu tanda kebangkitan Islam adalah lahirnya lembaga-lembaga keuangan Islam. Di antara lembaga keuangan Islam yang lahir adalah Perbankan Islam (Islamic Banking). Sejak pertengahan 1970-an, perbankan Islam telah meluas dan sudah beroperasi lebih dari 70 negara meliputi sebagian besar dunia muslim. Pada tahun 1997 aset total bank-bank yang melaporkan data keuangannya ke Internastional Association of Islamic Banks (IAIB) sebanyak 176 bank adalah US \$ 148 milyar (Al-Gaoud \& Lewis, 2004). Berdasarkan beberapa estimasi tertentu (yang mungkin terlalu optimis) lebih dari setengah simpanan tabungan dunia Islam di masa mendatang akan dikelola oleh institusi-institusi keuangan Islam (Warde, 2009).

Di Indonesia, gagasan untuk mendirikan bank syariah sebenarnya sudah muncul sejak pertengahan tahun 1970-an, namun belum terealisasi.Pada akhirnya gagasan tersebut muncul lagi pada tahun 1988, dan pada tahun 1991 ditanda tanganilah akte pendirian PT. Bank Mu'amalat Indonesia (Sudarsono, 2004). Dan setelah itu, lahirlah bermacam-macam lembaga keuangan syariah baik berbentuk bank maupun non bank seperti BPRS (Bank Pembiayaan Rakyat Syariah), BMT (Baitul Mal Watamwil), Kopsyah (Koperasi Syariah), KJKS (Kopersi Jasa Keuangan Syariah), Pegadaian Syariah, Asuransi Syariah, Leasing Syariah dan lain-lain dan bahkan bank-bank yang menggunakan sistem bunga pun meng-invansi-kan sayapnya membuka cabang syariah atau Unit Usaha Syariah (UUS). Bahkan ada yang langsung langsung menjadi Bank Umum Syariah.

Pada perbankan syariah banyak sekali akad-akad berdasarkan akad syariah, diantaranya funding (Penghimpunan Dana), financing (Penyaluran Dana), dan Fee Based Service (Multijasa Perbankan). Funding diantaranya Wadi'ah dan Mudharabah, Financing yang berbentuk jual beli; Murabahah, Salam, Istishna, yang berbentuk bagi hasil; mudharabah, musyarakah, dan yang berbentuk sewa menyewa; ijarah. Sedangkan yang berbentuk fee based services; hiwalah, rahn, Kafalah, sharf, serta transaksi kartu kredit syariah.

Pada perbankan syariah, baik itu bank umum maupun BPRS dalam akad pembiayaan/penyaluran dana tidak akan terlepas dari akan jual beli atau murabahah. Bahkan akad murabahah menempati urutan yang terbesar dalam penyaluran dananya ke nasabah. karena mudah diterapkan dalam pelaksanaan nya baik bagi pihak bank maupun nasabahnya.

Jual beli ini dibagi oleh para fuqaha' ke dalam beberapa pembagian, adapun berdasarkan pada cara penetapan harga produk jual beli tersebut dibagi kepada tiga macam yaitu: 
musawamah, muzayadah dan amanah. Jual beli amanah dibagi lagi kepada tiga macam yaitu murabahah, tauliyah dan wadh'iyah. Dengan demikian, pembiayaan murabahah sesungguhnya adalah salah satu bentuk jual beli.

Namun demikian, kemunculan lembaga-lembaga keuangan syariah hari ini khusus di Indonesia tidak didukung penuh oleh umat Islam. Di antara alasan yang banyak dilontarkan adalah keserupaan sistem Bank Syariah tersebut dengan bank konvensional yang menerapkan sistem bunga. Di antara produk bank yang dianggap serupa oleh masyarakat adalah pembiayaan Murabahah. Adapun kritik pokok terhadap pembiayaan ini adalah dengan risiko yang rendah dan bersifat jangka pendek, bank Islam tidak berhasil memenuhi misi utama perbankan Islam yaitu Profit and Loss Sharing (PLS). Risiko yang dijalani oleh bank sangat minim dan margin telah ditentukan di awal. Terlebih lagi, asset pembelian dijadikan sebagai garansi dan bank juga bisa meminta nasabahnya untuk memberikan suatu jaminan tertentu. Kombinasi dari keuntungan tetap dan jaminan memastikan bahwa risiko yang ditanggung oleh bank adalah sangat kecil.

Skema yang digunakan meniru perbankan konvensional dengan menyamarkan keuntungan melalui permainan kata-kata atau hiyal (tipu muslihat) lainnya. Melihat alasan yang disampaikan oleh masyarakat, seolah-olah kita mendengar ucapan orang-orang kafir di masa turunnya ayat penghalalan jual beli dan pengharaman riba.Mereka mengatakan, "Sesungguhnya jual beli itu adalah seperti riba".

Padahal murabahah adalah salah satu bentuk dari akad jual beli yang telah disahkan oleh Islam dan telah dipraktekkan sejak lama, dan tidak ada seorang ulama pun yang mengingkari keabsahannya. Namun, pada zaman dulu praktek akad murabahah masih dilakukan oleh seorang pembeli kepada seorang penjual. Sedangkan pada saat ini, akad murabahah berimplementasi antara seorang nasabah dengan Bank dan bahkan melibatkan pihak ketiga (supplier/penyedia) karena bank tidak memiliki barang, sehingga terjadi beberapa akad dan wa'ad (janji) sebelum akad murabahah tersebut terlaksana yang dalam istilah para ulama kontemporer disebut dengan murabahah murakkabah.

Dalam konotasi Islam, murabahah pada dasarnya berarti penjualan. Satu hal yang membedakannya dengan cara penjualan yang lain adalah bahwa penjual dalam model murabahah secara jelas memberi tahu kepada pembeli berapa nilai pokok barang tersebut dan berapa besar keuntungan yang dibebankannya pada nilai tersebut. Keuntungan bisa berupa lump sum atau berdasarkan persentase (Sutedi, 2009). 
Penerapan akad pembiayaan murabahah bank syariah di Indonesia mempunyai acuan yang telah ditetapkan oleh Dewan Syariah Nasional Majelis Ulama Indonesia atau yang disingkat dengan (DSN-MUI), selaku bank syariah sudah seharusnya dalam penerapan pembiayaan murabahah mengikuti fatwa ini, karena sudah menjadi rujukan bank syariah di Indonesia yang didalamnya diisi oleh Dewan Pengawas Syariah (DPS). Yang kita ketahui bahwa setiap bank syariah diharuskan memiliki DPS.

Dalam penentuan margin murabahah dari setiap bank, bank mempunyai cara tersendiri, dan relatif tidak ada yang sama antara bank satu dengan bank yang lain. Melihat kondisi ini penulis mencoba untuk menganalisis penerapan pembiayaan murabahah di bank syariah, seperti kita ketahui bahwa riau memiliki bank syariah sudah relatif sangat banyak, diantaranya: Bank Muamalat Indonesia, Bank Syariah Mandiri, BNI Syariah, BRI Syariah, Bank Permata Syariah, Bank Mega Syariah, Bank Riau Syariah, ditambah bank-bank daerah yang sudah resmi mengkonversikan menjadi bank syariah dan lain-lain.

Penulis akan mengambil satu bank syariah swasta nasional yang ada di Indonesia khususnya di Pekanbaru sebagai objek dari penelitian ini, penulis memilih Bank Rakyat Indonesia Syariah Pekanbaru atau disingkat BRI Syariah Pekanbaru. Karena penulis lihat perkembangan BRI Syariah Pekanbaru yang sangat pesat sejak di spin-off dari Unit Usaha Syariah menjadi Bank Umum Syariah, penulis tertarik untuk lebih dalam membahas penerapan pembiayaan akad murabahan di BRI Syariah Pekanbaru ini. Perkembangan omzet Bank Rakyat Indonesia Syariah (BRI) Syariah Pekanbaru mulai dari tahun 2010-2013, dapat dilihat pada tabel 1 di bawah ini. 
Tabel 1

Omzet BRI Syariah

\begin{tabular}{|c|c|c|c|c|c|}
\hline \multirow{3}{*}{ No } & \multirow{3}{*}{ KC PKU } & \multicolumn{4}{|c|}{ KC PEKANBARU } \\
\hline & & \multicolumn{4}{|c|}{ LAPORAN AKHIR TAHUN } \\
\hline & & 31 Des 10 & 31 Des 11 & 31 Des 12 & 31 Des 13 \\
\hline 1 & $\begin{array}{l}\text { Piutang Murabahah } \\
\text { MK Ib }\end{array}$ & 6.130.789.342,81 & 4.616.932.915,41 & 4.272.658.167,10 & 4.751.210.139,04 \\
\hline 2 & $\begin{array}{l}\text { Margin Ditangguh- } \\
\text { kan Murabahah } \\
\text { MK iB }\end{array}$ & $(1.172 .807 .738,14)$ & $(837.767 .572,07)$ & $(765.052 .923,73)$ & $(647.544 .204,34)$ \\
\hline 3 & $\begin{array}{l}\text { Piutang Murabahah } \\
\text { InvestasiiB }\end{array}$ & 43.262.016.749,77 & $111.821 .204 .448,59$ & 136.598.699.803,21 & 142.956.883.437,85 \\
\hline 4 & $\begin{array}{l}\text { Margin } \\
\text { Ditangguhkan- } \\
\text { Murabahah Inv iB }\end{array}$ & $(9.731 .423 .843,98)$ & $(22.140 .571 .436,87)$ & $(21.496 .328 .338,80)$ & $(23.678 .044 .989,45)$ \\
\hline 5 & $\begin{array}{l}\text { Piutang Murabahah } \\
\text { Konsumsi iB }\end{array}$ & 91.443.168.423,62 & $92.884 .821 .138,80$ & 129.075.320.641,80 & $163.567 .773 .484,29$ \\
\hline 6 & $\begin{array}{l}\text { Margin } \\
\text { Ditangguhkan- } \\
\text { Murabahah Kons } \\
\text { iB }\end{array}$ & $(37.665 .541 .901,26)$ & $(36.846 .750 .852,18)$ & $(50.618 .577 .386,20)$ & $(64.476 .485 .278,65)$ \\
\hline 7 & $\begin{array}{l}\text { Piutang Murabahah } \\
\text { Mikro iB }\end{array}$ & 0,00 & $33.522 .460 .218,47$ & 47.927.671.352,93 & $59.900 .986 .109,50$ \\
\hline 8 & $\begin{array}{l}\text { Margin Ditangguh- } \\
\text { kan Murabahah } \\
\text { Mikro iB } \\
\end{array}$ & 0,00 & $(9.260 .833 .538,09)$ & $(12.042 .832 .058,95)$ & $(15.107 .494 .944,84)$ \\
\hline \multicolumn{2}{|c|}{ Total Piutang Murabahah } & 140.835.974.516,20 & 242.845.418.721,27 & 317.874.349.965,04 & $371.176 .853 .170,68$ \\
\hline \multicolumn{2}{|c|}{$\begin{array}{c}\text { Total Margin } \\
\text { Ditangguhkan Murabahah }\end{array}$} & $(48.569 .773 .483,38)$ & $(69.085 .923 .399,21)$ & $(84.922 .790 .707,68)$ & $(103.909 .569 .417,28)$ \\
\hline
\end{tabular}

Sumber: PT. Bank BRI Syariah Kantor Cabang Pekanbaru

Dari tabel di atas terlihatlah dengan jelas jumlah piutang murabahah dan margin yang ditangguhkan oleh PT. Bank BRI Syariah Kantor Cabang Pekanbaru mengalami fluktuasi, namun secara umum mengalami kenaikan, walaupun kenaikannya tidak terlalu signifikan.

Berikut ini adalah gambaran persentase margin pembiayaan Murabahah Bank Rakyat Indonesia Syariah Pekanbaru yang mengalami perubahan persentase, ada yang naik dan ada yang tetap, namun jika dirata-ratakan persentasenya naik, dapat dilihat dari tabel di bawah ini: 
Tabel 2

Persentase Pembiayaan Murabahah

\begin{tabular}{|c|c|c|c|c|}
\hline \multicolumn{2}{|c|}{ Pembiayaan } & Sebelumnya & Rekomendasi & Ket \\
\hline \multicolumn{5}{|c|}{ Konsumer } \\
\hline $\mathrm{A}$ & \multicolumn{4}{|c|}{ KPR (Kredit Prumahah Rakyat) Mantap } \\
\hline & Jk. Waktu s/d 5 Th & $15,00 \% \mathrm{pa}$ & $15,50 \%$ pa & Naik \\
\hline & Jk. Waktu $>5$ s/d 10 Th & $16,00 \%$ pa & $16,50 \%$ pa & Naik \\
\hline & Jk. Waktu $>10$ s/d 15 Th & $17,00 \%$ pa & $17,50 \%$ pa & Naik \\
\hline \multirow[t]{5}{*}{$\mathrm{B}$} & \multicolumn{4}{|c|}{ KMG (Kredit Multi Guna)/KMJ (Kredit Multi Jasa) } \\
\hline & Kategori A & $15,00 \%$ pa & $15,50 \%$ ра & Naik \\
\hline & Kategori B & $16,00 \%$ pa & $16,50 \%$ pa & Naik \\
\hline & Kategori C & $17,00 \%$ pa & $17,50 \%$ pa & Naik \\
\hline & Kategori D & $18,00 \%$ pa & $18,50 \%$ pa & Naik \\
\hline \multirow[t]{6}{*}{$\mathrm{C}$} & \multicolumn{4}{|c|}{ KKB (Kredit Kendaraan Bermotor) } \\
\hline & Jk. Waktu s/d 1 Tahun & $15,00 \%$ ра & $15,50 \%$ pa & Naik \\
\hline & Jk. Waktu >1 - 2 Tahun & $15,50 \%$ ра & $16,00 \%$ pa & Naik \\
\hline & Jk. Waktu >2 - 3 Tahun & $16,00 \%$ ра & $16,50 \%$ pa & Naik \\
\hline & Jk. Waktu >3 - 4 Tahun & $17,00 \%$ ра & $17,50 \%$ ра & Naik \\
\hline & Jk. Waktu >4 - 5 Tahun & $18,00 \%$ pa & $18,50 \%$ pa & Naik \\
\hline$\overline{\mathrm{D}}$ & DTH (Dana Talangan Haji) & $15,00 \% \mathrm{pa}$ & $15,50 \% \mathrm{pa}$ & Naik \\
\hline \multirow[t]{3}{*}{$\mathrm{E}$} & \multicolumn{4}{|c|}{ KLM/PKE (Pembiayaan Kepemillikan Emas) } \\
\hline & Jk. Waktu 2-3Th & $17,00 \%$ ра & $17,00 \%$ pa & Naik \\
\hline & Jk. Waktu >3-5 Th & $18,00 \%$ pa & $18,00 \%$ pa & Naik \\
\hline \multirow[t]{3}{*}{$\bar{F}$} & \multicolumn{4}{|l|}{ Gadai } \\
\hline & Perhiasan & $18,00 \%$ pa & $18,00 \%$ pa & Tetap \\
\hline & LM & $15,00 \%$ ра & $16,00 \%$ ра & Naik \\
\hline
\end{tabular}

Sumber: PT. Bank BRI Syariah Kantor Cabang Pekanbaru

Dari tabel di atas terlihatlah persentase masing-masing jenis pembiayaan murabahah yang digunakan oleh PT. BRI Syariah pekanbaru. Mulai dari Kredit Perumahan Rakyat (KPR), Kredit 
Multi Guna (KMG)/Kredit Multi Jasa (KMJ), Kredit Kendaraan Bermotor (KKB), Dana Talangan Haji (DTH), Kepemilikan Logam Mulia (KLM)/ Pembiayaan Kepemillikan Emas (PKE), dan gadai.

Dan berdasarkan latar belakang tersebut, penulis ingin melakukan penelitian terhadap penerapan pembiayaan akad murabahah yang digunakan oleh BRI Syariah Pekanbaru. Berdasarkan uraian latar belakang dan batasan masalah di atas, penulis merumuskan bagaimanakah penerapan pembiayaan akad murabahah yang digunakan BRI Syariah Pekanbaru?

\section{LANDASAN TEORI}

\section{Margin}

Margin berdasarkan Kamus Besar Bahasa Indonesia Pusat Bahasa adalah: Margin adalah laba kotor atau tingkat selisih antara biaya produksi dan harga jual di pasar (Kebudayaan, 2020). Menurut informasi dari redaksi tazkia Pengertian margin adalah kenaikan bersih dari aset bersih sebagai akibat dari memegang aset yang mengalami pening-katan nilai selama periode yang dipilih oleh pernyataan pendapatan. Keuntun-gan juga bisa diperoleh dari peminda-han saling tergantung insidental yang sah dan yang tidak saling tergantung, kecuali transfer yang tidak saling ter-gantung dengan pemegang saham, atau pemegang- pemegang rekening investasi tak terbatas dan yang setara dengannya.

Profit margin adalah presentase spread yang ditetapkan pada kebijakan pricing pinjaman yang terutama ditujukan untuk memperoleh ROA (Return on asssets) yang ditargetkan. Cost to service merupakan persentaase yang dibebankan atas biaya yang dikeluarkan penghimpunan dana di luar bunga dan administrasi rekening dana dan pinjaman. Credit premium adalah penambahan persentasi evaluasi risiko industri dan usaha. Cost of fund adalah komponen utama kebijakan pricing yang dihitung atas dasar hasil murni suku bunga dana dengan mempertimbangkan aspek dana yang dipinjamkan (Djinarto, 2000).

Berdasarkan definisi diatas dapat disimpulkan bahwa margin adalah tingkat selisih atau kenaikan nilai dari aset yang mengalami peningkatan nilai dari biaya produksi dan harga jual. 


\section{Bank}

Menurut Undang-Undang Republik Indonesia No. 21 Tahun 2008 Tentang Perbankan Pasal 1 Ayat 2 Bank adalah badan usaha yang menghimpun dana dari masyarakat dalam bentuk Simpanan dan menyalurkannya kepada masyarakat dalam bentuk kredit dan/atau bentuk lainnya dalam rangka meningkatkan taraf hidup rakyat. Adapun Bank Umum Syariah adalah Bank Syariah yang dalam kegiatannya memberikan jasa dalam lalu lintas pembayaran. Sedangkan Menurut Undang-Undang Republik Indonesia No. 21 Tahun 2008 Tentang Perbankan Pasal 1 Ayat 9 Bank Pembiayaan Rakyat Syariah (BPRS) adalah Bank Syariah yang dalam kegiatannya tidak memberikan jasa dalam lalu lintas pembayaran.

\section{Murabahah}

Murabahah (مرابحة) secara bahasa bermakna pemberian keuntungan. Kata Murabahah

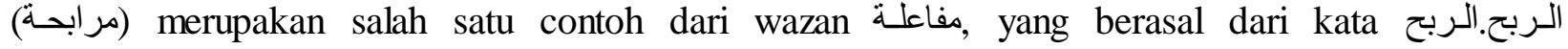
maknanya adalah النمـاء في التجر (pertumbuhan dalam perdagangan) (Manzhur, 2005). maka bagi orang Arab seseorang itu dianggap untung kalau aset dagangannya tumbuh/bertambah, hal ini senada dengan ayat Al-Qur'an;

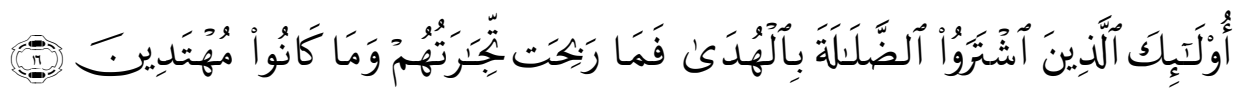

Artinya:"Mereka Itulah orang yang membeli kesesatan dengan petunjuk, Maka tidaklah beruntung perniagaan mereka dan tidaklah mereka mendapat petunjuk.” (QS. Al-Baqarah: 16).

Ketika disebutkan pembayaran produk ini adalah dengan caramurabahah dimana setiap sepuluh dirham diambil keuntungan satu dirham atau ketika seseorang berkata saya menjualnya dengan cara murabahah maka orang tersebut harus menyebutkan keuntungan yang dia ambil. Oleh sebab itu, dalam akad murabahah penyebutan jumlah keuntungan yang diambil oleh penjual adalah sebuah kemestian.

Walaupun murabahah berwazan mufa'alah, tetapi tidak bermakna saling menguntungkan karena dalam murabahah yang mendapat keuntungan hanya penjual, tetapi murabahah disini bermakna memberikan keuntungan (إرباح) (Al-Khursyi, $1317 \mathrm{H})$.

Adapun murabahah secara istilah menurut Muhammad Sholah Muhammad Ash-Showy dalam kitab Muykitatul Istitsmar yaitu jual beli barang dengan harga perolehan ditambah dengan 
keuntungan yang ditentukan.Ini adalah makna yang disepakati oleh para fuqaha' walaupun mereka berbeda dalam ungkapan lafadz.

Dalam kitab Al-Hidayah disebutkan bahwa definisi murabahah adalah perpindahan sesuatu yang dimiliki dengan akad yang pertama dan harga yang pertama ditambah dengan keuntungan (Al-Marghinany, 2000 M). Al-Kasani mendefinisikan murabahah yaitu jual beli dengan harga pembelian pertama ditambah keuntungan (Al-Kasany, 2005). Dalam kitab AlMughny, definisi murabahah adalah jual beli dengan modal ditambah keuntungan (Qudamah, 2005).

Dalam kitab Al-Majmu’ disebutkan bahwa murabahah adalah akad yang didasarkan pada harga yaitu harga pertama ditambah keuntungan misalnya seseorang membeli sebuah barang dengan harga Rp. 100,00 kemudian dia berkata kepada orang lain saya menjual barang ini kepadamu dengan harga pembelianku ditambah keuntungan (An-Nawawy, 2004). Ulama Malikiyah mendefinisikan murabahah yaitu penjual memberitahukan harga pembeliannya dan mengambil keuntungan dari harga tersebut baik secara umum seperti keuntungan satu dinar, terperinci seperti setiap satu dinar beri keuntungan satu dirham atau dengan ukuran sepersepuluh (Kuwait, 2006).

\section{Hukum Jual Beli Murabahah}

Dalam catatan Imam Muhammad Amin bin Umar yang lebih popular dengan sebutan Ibnu Abidin, dan catatan Ibnu Hazem bahwa murabahah adalah sistem jual beli yang diciplak dari negara Persia (salah satu Negara adidaya disaat itu) oleh masyarakat Arab Islam dalam aktivitas bisnis mereka pada abad pertama hijriah. Murabahah lebih dikenal dengan: "ده يازد", , maksudnya: "saya menjual barang kepadamu dengan keuntungan 1 dirham dari setiap 10 dirham".

Seiring perkembangannya, murabahah akhirnya menjadi sistem jual beli yang dilegitimasi oleh para ulama klasik, bahkan keabsahannya merujuk kepada konstitusi ulama (j̈ma'), Imam Al-Kasani (dari ulama Hanafi) menjelaskan bahwa sepanjang sejarah semenjak diperaktekan sistem murabahah dari generasi ke generasi tidak ada segelintir komunitas muslim dan ulama yang mengingkari akan keabsahanya sistem jualbeli murabahah (Al-Kasany, 2005). Hal itu dapat dijadikan rujukan sebagai bentuk ijma', disamping itu ada banyak alasan sistem jual-beli murabahah ini diterima oleh banyak kalangan. 
Jadi, jual beli murabahah termasuk transaksi yan dibolehkan oleh syariat. Mayoritas ulama, dari kalangan para sahabat, tabi'in dan para Imam mazhab, juga membolehkan jual beli jenis ini. Adapun dalil jumhur dalam membolehkan akad murabahah adalah keumuman dalildalil tentang pembolehan akad jual beli baik dari Al-Qur'an maupun hadits (Thahmaz, 2001). Diantaranya adalah firman Allah SWT :

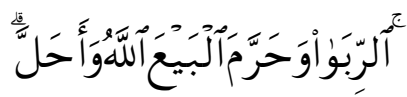

Artinya:"Padahal Allah telah menghalalkan jual beli dan mengharamkan riba” (QS. AlBaqarah: 275)

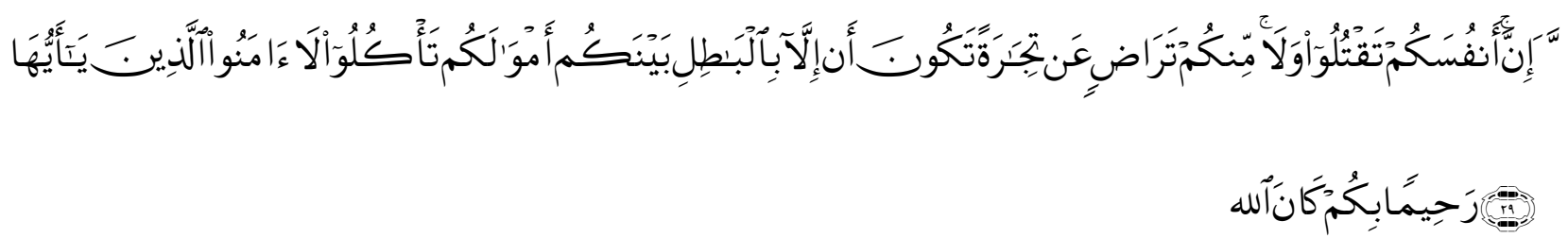

Artinya:"Hai orang-orang yang beriman, janganlah kamu saling memakan harta sesamamu dengan jalan yang batil, kecuali dengan jalan perniagaan yang Berlaku dengan suka sama-suka di antara kamu. dan janganlah kamu membunuh dirimu; Sesungguhnya Allah adalah Maha Penyayang kepadamu.” (QS. An-Nisa: 29)

Sabda Rasulullah SAW:

$$
\text { إنما البيع عن تراض (رواه ابن ماجه وصححه الباني) }
$$

Artinya: "Sesungguhnya jual beli itu dilandasi oleh saling redho". (HR. Ibnu Majah dan dishohehkan oleh Syekh Al-Bany).

Sementara murabahah adalah jual beli yang didasarkan pada saling ridho antara dua pihak yang bertransaksi.Jumhur ulama juga beralasan bahwa dalam akad jual beli murabahah ini semua syarat-syarat terpenuhi dan akad ini sangat dibutuhkan.Karena orang yang bodoh yang tidak paham tentang perdagangan, dia sangat butuh atas berita dari orang yang paham.Selain itu, murabahah adalah jual beli barang dengan harga yang jelas (Az-Zuhaily, 2004).

Hanya saja, menurut ulama Malikiyah jual beli ini hukumnya khilaful aula karena memerlukan banyak penjelasan yang kadang-kadang sulit bagi masyarakat umum sehingga jual beli itu menjadi rusak.Penjual harus menjelaskan barangnya dan semua biaya yang dikekuarkan untuk mendapatkan barang tersebut (untuk kemudian diperhitungkan) sebagai tambahan harga; 
dan tidak mustahil menimbulkan perselisihan (Al-Jazairy, 2000), sedangkan Ibnu Hazam berpendapat murabahah hukumnya haram dengan alasan bahwa syarat keuntungan harus diberitahukan adalah syarat yang tidak ada dalam Al-Qur'an, sehingga jual beli ini adalah jual beli dengan harga yang tidak jelas. Hanya saja beliau membolehkan bagi seseorang yang berada di suatu negeri dimana tidak ada sistem jual beli kecuali dengan sistem ini.

Menurut ulama Hanabilah murabahah hukumnya ada dua macam:

a) Hukumnya boleh tanpa ada perdebatan, yaitu jika keuntungan itu disebutkan secara lansung dan tidak ada kaitan dengan modal, seperti seseorang berkata : aku membelinya dengan harga Rp. 1.000,00 dan aku jual kepadamu dengan mengambil keuntungan Rp. 100,00; b) Hukumnya makruh jika keuntungan yang diambil merupakan bagian dari modal, seperti seseorang berkata: saya mengambil keuntungan Rp. 10,00 pada setiap Rp. 100,00 (Al-Jazairy, 2000); c) Bentuk ini juga dimakruhkan oleh Ibnu Umar, Ibnu Abbas, Al-Hasan, Masruq, Ikrimah, Said bin Jubair dan Atha' bin Yasar. Adapun Alasan Ibnu Umar dan Ibnu Abbas memakruhkan bentuk ini karena ada semamcam ketidakjelasan berapa keuntungan yang diambil. Dengan demikian, jika ketidakjelasan itu bisa dihilangkan maka hukumnya menjadi boleh (Al-Mawardi, 2009).

\section{Metode Pengambilan Keuntungan Dalam Murabahah}

Metode Penentuan Margin menurut adalah sebagai berikut Metode penentuan margin terdiri dari (Muhammad, 2005): a) Mark up Pricing, Mark up pricing adalah penentuan ting-kat harga dengan me-markup biaya produksi komoditas yang bersangkutan; b) Target Return Pricing, Target Return Pricing adalah harga jual produk yang bertujuan mendapatkan tingkat return atas besarnya modal yang diinvestasikan. Dalam bahasan keuangan dikenal dengan return on investment (ROI). Dalam hal ini perusahaan akan menentukan berapa return yang akan diharapkan atas modal yang dïnvestasikan.

Adapun metode untuk menetapkan keuntungan dalam murabahah ada tiga macam:

a) Keuntungan itu dalam bentuk persentase dari modal, seperti $10 \%$, $5 \%$ dan seterusnya. Contoh : Aku jual barang ini kepadamu dengan modal Rp. 1.000,00 ditambah laba 10 \% atau 5 \% dari jumlah modal; b) Keuntungan itu dalam bentuk yang terpisah dari modal. Contoh : Aku jual barang ini kepadamu dengan modal Rp. 1.000,00 ditambah laba Rp. 100,00; c) Keuntungan itu adalah lump sum (sekaligus) ditambah lagi dengan persentase tertentu. Contoh: Saya telah membeli barang ini Rp. 1.000,00, saya jual kepadamu Rp. 2.000,00 dan ditambah laba $10 \%$. 
Dalam jual beli murabahah secara umum semua syarat yang ada dalam akad jual beli juga berlaku padanya. Seperti, barang yang diperjual belikan harus dimiliki oleh penjual atau diizinkan dalam menjualnya, bentuk barang harus jelas baik dengan cara melihat secara lansung atau mengetahui sifat-sifatnya, harus bisa diserahterimakan, harga harus jelas, saling ridho, cakap secara hukum dan seterusnya.

Dalam pembahasan selanjutnya, syarat-syarat yang dibahas hanyalah syarat-syarat khusus untuk akad murabahah karena itulah tujuan dasar dari penelitian ini. Dan juga akan dijelaskan tentang biaya-biaya yang bisa dibebankan kepada modal dan yang tidak bisa dibebankan.

Syarat-syarat yang harus dipenuhi dalam transaksi murabahah agar menjadi sah adalah sebagai berikut:a) Modal harus diketahui atau diberitahukan kepada pembeli. Karena mengetahui modal adalah syarat sahnya transaksi murabahah maka jika tidak diketahui oleh pembeli atau tidak diberitahukan oleh penjual maka transaksi tersebut batal (Al-Kasany, 2005). Hal ini juga yang membedakan murabahah dengan musawamah; b) Keuntungan yang diambil penjual harus jelas. Mengetahui keuntungan yang diambil adalah hal yang sangat penting dalam transaksi murabahah karena keuntungan adalah bagian dari harga.Mengetahui harga adalah syarat sahnya transaksi jual beli, maka jika harga tidak jelas dalam transaksi, murabahah tidak boleh dilakukan.Sama saja apakah penetapan keuntungan secara lansung dan tersendiri atau dengan persentase, apakah dibayar secara tunai atau kredit; c) Modal yang dikeluarkan hendaknya berupa barang mitsliyat. Modal itu ada dua macam yaitu mitsly atau qimy. Mitsly atau mitsliyat adalah barang-barang yang tersedia di pasar dan memiliki satu ukuran yaitu timbangan, takaran atau ukuran, panjang, dan perhitungan dengan selisih yang tidak beda jauh (Hammad, 1995). Jika dihitung dengan selisih berbeda jauh, maka tidak disebut mitsly (Al-Jazairy, 2000). Mitsly disebut juga dengan barang yang mempunyai kesamaan standard, seperti Rupiah, Ringgit atau mata uang lainnya atau berupa barang yang ditakar atau ditimbang dan dihitung.

Adapun qimy adalah barang yang tidak memiliki kesamaan standard, melainkan bersifat taksiran, seperti barang dagangan, hewan, pohon, pakaian, tanah dan lain-lain atau barang yang tidak memiliki varian serupa (Hammad, 1995).

Maka jika modalnya mitsly boleh dimurabahahkan dengan harga pertama, terlepas dari penjualan tersebut dilakukan dengan penjual pertama atau orang lain, juga terlepas dari apakah 
keuntungan yang diminta serupa dengan modal pertama atau tidak (setelah harga pertama dan keuntungan jelas).

Para ulama hanafiyah menjelaskan bahwa jika modal qimy seperti barang dagangan (arab: 'urudh yaitu segala sesuatu selain dinar dan dirham), tidak boleh dimurabahahkan kepada orang yang tidak memiliki barang dagangan tersebut. Karena murabahah adalah menjual sesuai dengan harga pertama (harga pembelian), jika harga pertama tidak sama jenisnya akan terjadi dua kemungkinan, pertama jual beli selain barang dagangan tersebut, atau kedua jual beli berdasarkan taksiran nilainya sedangkan bendanya tidak dia miliki. Taksiran nilai setiap orang menaksir akan berbeda-beda, hal ini menimbulkan ketidakjelasan atau jahalah.

Namun, jika dimurabahahkan kepada orang yang memiliki dan menguasai barang dagangan, maka dilihat jika keuntungan terpisah dari modal dan jelas seperti Rp. 1.000,00 atau pakaian tertentu maka hukumnya boleh.Karena harga pertama dan keuntungan jelas.Jika keuntungan ditetapkan dari bagian modal seperti 10 \% dari modal hukumnya tidak boleh, karena keuntungan tidak jelas (Al-Kasany, 2005).

Menurut ulama mlikiyah jika harga pertama adalah barang dagangan, maka ada dua kemungkinan, yaitu: a) Pembeli tidak memilikinya.

Jika pembeli tidak memiliki barang dagangan tersebut, maka tidak boleh dimurabahahkan sama saja apakah harga pertama itu mitsly atau qimy, ini adalah pendapat Asyhab, sedangkan Ibnul Qasim berpendapat jika mitsly maka boleh dijual dengan murabahah baik pembeli memiliki barang dagangan tersebut atau tidak; b) Pembeli memilikinya. . Jika harga pertama itu berupa qimy, maka Asyhab berpendapat tidak boleh dimurabahahkan, sedangkan Ibnul Qasim membolehkannya dengan syarat dijual dengan barang yang sama ditambah keuntungan, dan tidak boleh dijual dengan cara taksiran (Al-Khursyi, $1317 \mathrm{H}$ ).

Ulama Syafi'iyah berpendapat bahwa jika seseorang membeli barang dengan modal barang dagangan dan ingin menjualnya dengan cara murabahah maka hukumnya sah dengan syarat menggunakan lafadz: Saya jual dengan modal pembelian saya atau saya jual dengan segala hal yang telah aku lakukan (Asy-Syarbiny, 1997). Jika modal pada transaksi pertama dan barang yang dibeli termasuk barang-barang ribawi, maka modal dan barang tersebut tidak boleh sejenis.

Harta-harta ribawi menurut ulama malikiyah adalah segala yang dimakan dan bisa disimpan, menurut ulama syafiiyah adalah setiap yang dimakan, sedangkan menurut ulama 
hanafiyah dan hanbilah adalah setiap yang ditakar atau ditimbang. Semua ulama sepakat bahwa emas dan perak serta uang kertas termasuk pada harta-harta ribawi.

Maka syarat ini disepakati oleh semua ulama, karena murabahah adalah penjualan dengan harga pertama ditambah keuntungan, sedangkan tambahan pada harta-harta ribawi adalah riba bukan keuntungan.Tetapi, jika berbeda jenis maka boleh di-murabahahkan dengan syarat tunai, seperti seseorang membeli satu dinar dengan sepuluh dirham, kemudian dia menjualnya dengan murabahah dan keuntungan yang dia tetapkan adalah satu dirham (Al-Kasany, 2005).

Berkenaan dengan riba selaras dengan penelitian yang ditulis oleh Nurjannah Septyanun, dkk, yang menyatakan bahwa meninggalkan pekerjaan riba adalah proses mengIslamkan sains dan sains Islam dalam ranah paradigma. Pemahaman tekstual tentang semua larangan, termasuk larangan riba, adalah salah satu alasan dikeluarkannya x bankir pekerjaan keagamaan. Teks-teks ayat dalam Al Qur'an dan Sunnah sangat memengaruhi pekerjaan institusi riba secara psikologis. Selanjutnya, studi Islam dari ulama / da'i / adzatidza didasarkan pada hierarki x-banker. Migrasi dan perbankan riba adalah dua variabel penting dalam penelitian ini terkait dengan populisme Islam. Migrasi dari riba berbasis perbankan tentang epistemologi membutuhkan metodologi yang tepat dan oleh pola-pola yang ada di masyarakat. Masayarakat Muslim Indonesia semakin menyadari bahwa mereka membutuhkan model yang tepat dalam menerapkan Islam. Metode pemurnian pemahaman adalah bagian dari Tauhid (Septyanun, Dimyati, Setiaji, \& Basri, 2019).

Transaksi pertama harus sah, jika fasid maka tidak boleh dimurabahahkan. Para ulama sepakat bahwa hukum jual beli fasid adalah pengembalian artinya penjual mengembalikan harga dan pembeli mengembalikan barang.Meskipun ulama hanafiyah berpendapat bahwa jual beli fasid masih memfaedahkan kepemilikan secara umum, tetapi kepemilikan itu ditetapkan berdasarkan taksiran harga barang atau semisalnya bukan berdasarkan harga yang telah disebutkan dalam akad yang telah rusak/fasid dan taksiran adalah sesuatu yang tidak jelas. Oleh sebab itu, jika akad pertama tidak sah maka tidak boleh di-murabahah-kan sebab adanya ketidakjelasan/jahalah. 


\section{METODE PENELITIAN}

\section{Tempat Dan Waktu Penelitian}

Tempat penelitian dilakukan di bank yaitu BRI Syariah Pekanbaru. Penelitian ini dilakukan selama \pm 5 bulan, mulai bulan Januari 2019-Mei 2019.

\section{Populasi Dan Sampel}

Populasi adalah jumlah keseluruhan dari satuan-satuan atau individu-individu yang karakteristiknya hendak diteliti. Dan satuan-satuan tersebut dinamakan unit analisis, dan dapat berupa orang-orang, institusi-institusi, benda-benda, dan seterusnya (Djarwanto, 1994). Populasi dalam penelitian ini adalah Pimpinan dan Karyawan Bagian Pembiayaan BRI Syariah.

Sampel atau contoh adalah sebagian dari populasi yang karakteristiknya hendak diteliti (Djarwanto, 1994). Adapun sampel dari penelitian ini adalah pimpinan BRI Syariah dan Karyawan Bagian Pembiayaan BRI Syariah. Penentuan sampel ini menggunakan metode snowball sampling.

Snowball sampling adalah teknik penentuan sampel yang mula-mula jumlahnya kecil, kemudian membesar. Ibarat bola salju yang menggelinding yang lama-lama menjadi besar. Dalam penentuan sampel, pertama-tama dipilih satu atau dua orang, tetapi karena dengan dua orang ini belum merasa lengkap terhadap data yang diberikan, maka peneliti mencari orang lain yang dipandang lebih tahu dan dapat melengkapi data yang diberikan oleh dua orang sebelumnya. Begitu seterusnya, sehingga jumlah sampel semakin banyak (Sugiyono, 2012).

\section{Teknik Pengumpulan Data}

Adapun teknik pengumpulan data yang penulis gunakan dalam penelitian ini adalah sebagai berikut: a) Teknik Wawancara, adalah dengan cara menanyakan langsung kepada bagian customer service bank tersebut yang berkaitan dengan masalah yang penulis teliti, kemudian dilanjutkan dengan wawancara terhadap bagian pembiayaaan bank dilanjutkan dengan pimpinan bank; b) Pengamatan/Observasi, adalah dengan cara melihat langsung ke lapangan di Bank tersebut; c) Teknik Dokumentasi, adalah dengan cara mengumpulkan dokumentasi dari bank, yang berhubungan dengan penelitian ini.

\section{Teknik Analisa Data}

Teknik analisa data yang digunakan dalam penelitian ini adalah dengan cara analisa kualitatif. Dalam penelitian ini data yang sudah dikumpulkan diolah untuk diklasifikasikan sesuai dengan jenis datanya. 


\section{HASIL DAN PEMBAHASAN}

Pembiayaan murabahah merupakan pembiayaan yang sangat laris di pasaran dunia perbankan Islam di Dunia, termasuk indonesia, hal ini selaras dengan penelitian yang pernah ditulis oleh Nurjannah S. dkk, yaitu Instrumen murabahah sebagai salah satu produk unggulan perbankan syariah dengan kontribusi signifikan selain dari penetapan standar untuk murabahah produk perbankan syariah oleh Otoritas Jasa Keuangan. Di sisi lain, rasanya sangat diperlukan untuk membangun paradigma entitas hukum yang praktis, dalam hal ini sumber daya manusia di perbankan. Karenanya, antara aspek normatif, interpretatif dan implementatif menjadi entitas keseluruhan dalam mendukung pengembangan perbankan syariah menuju perbankan yang bukan hanya bank biasa dan memperkuat karakteristik norma perbankan yang merupakan dasar fundamental (Septyanun, Haq, Dimyati, \& Setiaji, 2018).

Penerapan pembiayaan murabahah BRI Syariah dapat diklasifikasikan mulai dari menentuan margin, penentuan suku bunga, hingga jika nasabah telat membayar bahkan jika tidak sanggup membayar tagihan.

\section{Metode Penetapan Margin}

Dalam metode penetapan margin pembiayaan murabahah BRI Syariah menggunakan persentase flat/tetap, namun BRI Syariah menggunakan persentase berjenjang, tidak setiap tahun margin yang diambil sama, tergantung dari lamanya pembiayaan, dan semua bank lebih mengutamakan instansi yang telah melakukan kerjasama dengan bank, seperti instansi pemerintah maupun swasta (Haris, 2019).

Dari penjelasan tersebut di atas dapat dijelaskan bahwa BRI Syariah menggunakan persentase tetap/flat, karena akad jual beli murabahah, mengharuskannya seperti itu, hal ini sesuai dengan konsep akad pembiayaan murabahah.

\section{Mengikuti Suku Bunga Bank Indonesia}

Margin yang diberlakukan oleh BRI Syariah menggunakan berjenjang, untuk 1-5 tahun ekuvalen ratenya sebesar 15,85\% per-tahun, untuk 6-10 tahun sebesar 16,25\% per-tahun, untuk 11-15 tahun sebesar 17,15 persen per-tahun. Ketetapan margin ditentukan oleh BRI Syariah Pusat yang berada di Jakarta oleh bagian financial control (Haris, 2019).

BRI Syariah masih mengikuti suku bunga yang berlaku pada BI (Bank Indonesia), bank ini menentukan margin pembiayaan murabahah masih menggunakan tingkat inflasi per- 
tahunnya. Semakin tinggi BI rate, maka semakin tinggi pula margin yang diambil oleh bank dari nasabah.

\section{Penggunaan Akad}

Dalam pembiayaan, BRI Syariah Pekanbaru, akad yang paling banyak digunakan akad murabahah, sangat sedikit persentase pembiayaan selain murabahah, seperti pembiayaan musyarakah, pembiayaan mudharabah, akad ijarah, akad salam, akad istishna dan lain-lain.

BRI Syariah Pekanbaru 90\% menggunakan akad murabahah, sangat sedikit menggunakan akad lain. Pembiayaan mikro semuanya menggunakan murabahah, pembiayaan ritel menggunakan beberapa akad, ada yang akad murabahah, akad musyarkah, dan akad mudharabah (Haris, 2019). Sehingga dapat dijelaskan bahwa persentase murabahah yang paling besar digunakan pada BRI Syariah Pekanbaru dibandingkan dengan akad-akad yang lain. Berikut ini adalah contoh pembiayaan murabahah yang dilakukan oleh BRI Syariah Pekanbaru.

Tabel 3.

Ilustrasi Pembiayaan Murabahah KPR iB BRI Syariah Pekanbaru

\begin{tabular}{|c|c|c|c|r|r|r|}
\hline \multirow{2}{*}{ No } & Margin & $\mathbf{9 , 0 9 \%}$ & $\mathbf{9 , 9 1 \%}$ & $\mathbf{1 0 , 2 9 \%}$ & $\mathbf{1 1 , 3 6 \%}$ & \multicolumn{1}{|c|}{$\mathbf{1 1 9 2 \%}$} \\
\cline { 2 - 7 } & Plafond & 5 Tahun & 8 Tahun & 10 Tahun & 12 Tahun & 15 Tahun \\
\hline 1 & 50.000 .000 & 1.211 .921 & 933.804 & 845.372 & 820.967 & 774.824 \\
\hline 2 & 60.000 .000 & 1.454 .306 & 1.120 .565 & 1.014 .446 & 985.160 & 929.789 \\
\hline 3 & 70.000 .000 & 1.696 .690 & 1.307 .326 & 1.183 .521 & 1.149 .354 & 1.084 .753 \\
\hline 4 & 80.000 .000 & 1.939 .074 & 1.494 .087 & 1.352 .595 & 1.313 .547 & 1.239 .718 \\
\hline 5 & 90.000 .000 & 2.181 .459 & 1.680 .848 & 1.521 .670 & 1.477 .740 & 1.394 .683 \\
\hline 6 & 100.000 .000 & 2.423 .843 & 1.867 .609 & 1.690 .744 & 1.641 .934 & 1.549 .648 \\
\hline
\end{tabular}

Sumber: BRI Syariah Pekanbaru

Dari tabel di atas terlihat bahwa persentase atau margin yang diambil oleh BRI Syariah Pekanbaru berdasarkan pokok pembiayaan, persentase margin dilihat berdasarkan jangka waktu, semakin lama jangka waktu pembiayaan maka semakin besar persentase margin yang diambil oleh BRI Syariah Pekanbaru.

\section{Pembiayaan Akad Murabahah Menggunakan Jaminan}

Pada pelaksanaannya pembiayaan yang dilakukan BRI Syariah jumlah flafond yang berbeda-beda, pada prinsifnya BRI Syariah memiliki unsur kehati-hatian dalam pemberian pembiayaan, sehingga pembiayaan murabahah yang dilakukan BRI Syariah Pekanbaru semuanya menggunakan menggunakan jaminan (Haris, 2019). 
Dari penjelasan tersebut di atas dapat dijelaskan bahwa BRI Syariah menggunakan jaminan pada setiap pembiayaan, hal ini tentunya bank mengambil salah satu konsep 5C (Character, Capacity, Capital, Condition, Collateral), 5C yang dimaksud adalah collateral (jaminan). Nasabah wajib menyiapkan jaminan pembiayaan, agar kalau terjadi hal-hal yang tidak dïnginkan maka bank bisa ambil tindakan terhadap jaminan tersebut. Tentunya jaminan yang diberikan nasabah lebih besar dari jumlah pembiayaan, besar pembiayaan yang diberikan sekitar $80 \%$ dari nilai pembiayaan.

\section{Penyelesaian Ketika Nasabah Pailit}

BRI Syariah memberikan solusi yaitu dengan menjual aset nasabah/perusahaan atau mengeksekusi jaminan, dengan cara memberikan kesempatan kepada nasabah untuk menjual sendiri atau jika belum terjual akan dijual langsung oleh bank melalui proses lelang, pertimbangan nasabah menjual sendiri, agar barang yang terjual harga masih tinggi, kalaupun yang menjual bank sisa dari penjualan proses lelang tadi, jika uangnya berlebih, akan diberikan kepada nasabah sejumlah pokok (Haris, 2019).

Sehingga dapat dijelaskan langkah terakhir dari BRI Syariah Pekanbaru adalah dengan cara mengeksekusi atau menjual jaminan yang dititipkan di bank, jika ada sisa maka, uang tersebut dikembalikan kepada nasabah.

\section{Penggunaan Uang Muka Dalam Pembiayaan Murabahah}

Ketika memberikan pembiayaan BRI Syariah mewajibkan nasabah untuk memberikan uang muka/down payment. BRI Syariah uang mukanya minimal 20\% dan maksimal untuk ritel 30\%, untuk rumah 20\% dan untuk kontraktor 50\% (Haris, 2019).

Dari penjelasan tersebut di atas bahwa, BRI Syariah mewajibkan kepada Nasabah untuk memberikan uang muka pada setiap pembiayaan akad murabahah, jumlahnya uang 20-50\% dari total pembiayaan, hal ini juga menjadi pertimbangan bank atas keseriusan nasabah dalam pembiayaan. Agar nasabah bersungguh-sungguh dalam pembiayaan ini. Karena ada uang nasabah juga, sehingga nasabah tidak lalai dalam pembiayaannya tersebut. Hal ini sesuai dengan fatwa DSN-MUI nomor: 13/DSN-MUI/IX/2000, tentang Uang Muka dalam Murabahah. 


\section{Pemberian Diskon Dalam Pembiayaan Murabahah}

BRI Syariah ada memberikan diskon kepada nasabah, maksimal jumlahnya sebesar Rp. 10.000.000, jika lebih dari Rp. 10.000.000, maka BRI Syariah Pekanbaru akan berkoordinasi terlebih dahulu kepada BRI Syariah Pusat, BRI Syariah Pekanbaru diberikan wewenang hanya berjumlah maksimal Rp. 10.000.000,-- Hal ini tetap melihat perkembangan dari nasabah, apakah layak diberikan diskon atau tidak (Haris, 2019).

Dari penjelasan tersebut di atas, BRI Syariah memberikan diskon pembiayaan kepada nasabah jumlah masksimal tertentu. Diskon tersebut diberikan kepada nasabah yang berprestasi, artinya melihat track record nasabah selama waktu pembiayaan, dilihat dari jumlah besar kecil pembiayaannya, waktu pembayaran apakah ada keterlambatan. Diskon tersebut tetap di bawah kontrol BRI Pusat di Jakarta. Hal ini juga sesuai dengan fatwa yang telah ditetapkan oleh DSNMUI nomor: 16/DSN-MUI/IX/2000, tentang Diskon dalam Murabahah.

\section{Sanksi Terhadap Nasabah Yang Menunda-nunda}

Sanksi terhadap nasabah yang menunda-nunda, BRI Syariah Pekanbaru memberikan surat peringatan mulai dari SP1, SP2, SP3, jika tidak merubah kebiasaan/karakter, maka langkah berikutnya adalah dengan cara memberikan denda per hari kepada nasabah tersebut, denda per hari itu karena bukan termasuk pendapatan bank, maka uang dari denda tersebut dipergunakan untuk keperluan fasilitas umum, kegiatan-kegiatan sosial, Corporate Social Responsibility (CSR), dan lain-lain (Haris, 2019).

Dari penjelasan tersebut di atas bahwa BRI Syariah akan memberikan surat peringatan pertama, kedua, dan ketiga. Jika memberikan denda kepada nasabah, agar ada efek jera terhadap kelalaian pembayaran angsuran pembiayaan, hal ini juga diatur dalam fatwa DSN MUI nomor: 17/DSN-MUI/IX/2000, tentang Sanksi atas Nasabah Mampu yang Menunda-nunda Pembayaran. Agar memberikan efek jera kepada nasabah dengan cara pembayaran denda, tentunya denda tersebut tidak dihitung sebagai pendapatan.

\section{Jika Nasabah Melunasi Pembiayaan Murabahah Sebelum Jatuh Tempo}

Dalam hal ini BRI Syariah Pekanbaru akan memberikan potongan margin bagi nasabah yang melunasi pembiayaan murabahahnya lebih cepat dari waktu yang telah dijadwalkan yang sesuai dengan kesepakatan sebelumnya (Haris, 2019).

Dari penjelasan tersebut dapat dijelaskan bahwa BRI Syariah memberikan potongan kepada nasabah, dengan cara membayar pokok pembiayaan saja, sedangkan margin tidak perlu 
dibayarkan, namun bank tetap akan mengambil beberapa bulan marginnya. Hal ini sesuai dengan fatwa DSN MUI nomor: 23/DSN-MUI/III/2002 tentang Potongan Pelunasan dalam Murabahah . Dalam fatwa tersebut dikatakan bahwa jika nasabah melunasi pembiayaan, maka yang dibayarkan hanya pokok pembiayaannya saja.

\section{Penyelesaian Piutang Murabahah Jika Nasabah Tidak Mampu Membayar}

Ketidakmampuan penyaluran dana dalam meningkatkan profitabilitas perbankan syariah disebabkan oleh tingginya pembiayaan bermasalah atau Non-Performing Financing (NPF) (Purwanto, 2019). BRI Syariah Pekanbaru memberikan sanksi bagi nasabah yang tidak sanggup membayar, berupa surat peringatan pertama, surat peringatan kedua, surat peringatan ketiga, dan terakhir eksekusi jaminan, namun bank tetap memberikan kesempatan untuk menjual jaminannya terlebih dahulu, jika tidak terjual maka jaminan akan dilelang (Haris, 2019).

Dari pernyataan tersebut di atas, sehingga dapat dijelaskan bahwa langkah terakhir atau solusi terkahir untuk penyelesaian piutang murabahah jika nasabah tidak mampu membayar hutangnya adalah dengan cara menjual jaminannya. Hal ini juga sesuai dengan fatwa DSN-MUI nomor: 47/DSN-MUI/II/2005, tentang Penyelesaian Piutang Murabahah bagi Nasabah Tidak Mampu Membayar.

\section{Rescheduling Bank Terhadap Nasabah}

BRI Syariah memberikan Rescheduling (penjadwalan kembali) atas nasabah yang tidak sanggup membayar, tanpa menambah margin. Bank juga memberikan restructuring (penstruktur kembali) dan reconditioning (pengkondisian kembali) terhadap nasabah sesuai dengan kesepakatan (Haris, 2019).

Dari penjelasan tersebut di atas dapat dijelaskan bahwa BRI Syariah memberikan kesempatan kepada nasabah untuk rescheduling (penjadwalan kembali), restructuring, dan reconditioning. Sehingga nasabah akan merasa terbantu dengan meringankan jumlah angsuran pembiayaan, walaupun secara periode waktu akan semakin lama. Hal ini sesuai dengan fatwa DSN MUI 48/DSN-MUI/II/2005 Penjadwalan Kembali Tagihan Murabahah menganjurkan kepada bank dan nasabah untuk membuat kesepakatan baru. Namun bank akan melihat kapasitas nasabah, apakah memang layak untuk rescheduling. 


\section{PENUTUP}

Sistem pelaksanaan pembiayaan murabahah pada bank bisa mulai dari syarat administrasi, syarat jaminan, syarat pembiayaan, plafond pembiayaan, jangka waktu pembiayaan, dan biaya yang dibebankan kepada nasabah. Dalam penetapan margin pembiayaan murabahah masih menggunakan tingkat inflasi per-tahunnya. Semakin tinggi BI rate, maka semakin tinggi pula margin yang diambil oleh bank dari nasabahnya. Bank menggunakan sistem wakalah dalam pembiayaan murabahah dan bank tidak menyediakan barang dagangan. Bank hanya melakukan kerjasama kepada penyedia barang dan ada juga nasabah diminta mencari dahulu penyedia barang. Bank memberikan potongan margin, ketika nasabah melunasi pembiayaan murabahahnya. Bank tidak hanya menggunakan akad murabahah, selain murabahah bank juga menggunakan akad musyarakah, dan mudharabah, dan porsi yang paling besar adalah akad murabahah. Bank menggunakan jaminan dalam melakukan pembiayaan murabahah dan Bank tidak menggunakan uang muka dalam melakukan pembiayaan murabahah. Bank juga memberikan sanksi bagi nasabah yang tidak sanggup membayar, berupa surat peringatan pertama, surat peringatan kedua, surat peringatan ketiga, dan terakhir eksekusi jaminan, namun bank tetap memberikan kesempatan untuk menjual jaminananya terlebih dahulu, jika tidak terjual maka jaminan akan dilelang. Bank memberikan rescedulling (penjadwalan kembali) atas nasabah yang tidak sanggup membayar, tanpa menambah margin. Bank juga memberikan restructuring dan reconditioning terhadap nasabah sesuai dengan kesepakatan.

\section{DAFTAR PUSTAKA}

Al-Gaoud, L. M., \& Lewis, M. K. (2004). Perbankan Syariah Prinsip Praktek Prospek. Jakarta: PT. Serambi Ilmu Semesta.

Al-Jazairy, A. (2000). Kitab Al-Fiqh 'Ala Al-Mazahib Al-Arba'ah. Kairo: Al-Maktab AtsTsaqafy.

Al-Kasany. (2005). Badai’ Ash-Shanai’ fi Tartib Asy-Syarai’. Kairo: Darul Hadits.

Al-Khursyi. (1317 H). Syarh Al-Muhaqqiq Al-Jihbidz Al-Fadhil Al-Mudaqqiq Sayyidi Abi Abdillah Muhammad Al-Khursyi 'alal Mukhtashar Al-Jalil Lil Imam Abidh Dhiya Sayyidi Khalil. Mesir: Al-Mathba’ah Al-Kubra Al-Amiriyah.

Al-Marghinany. (2000 M). Al-Hidayah Syarh Bidayatul Mubtadi. Beirut: Darul Kutub AlIlmiyah. 
Al-Mawardi. (2009). Al-Hawil Kabir. Lebanon: Darul Kutub Al-Ilmiyah.

An-Nawawy. (2004). Al-Majmu’ Syarh Al-Muhazdzdab. Beirut: Darul Fikr.

Asy-Syarbiny, S. M.-K. (1997). Mughnil Muhtaj Ila Ma'rifah Ma'ani Alfadzil Minhaj. Beirut: Darul Ma'rifah.

Az-Zuhaily, W. (2004). Al-Fiqhul Islami wa Adillatuhu. Damaskus: Darul Fikr.

Djarwanto. (1994). Pokok-pokok Metode Riset dan Bimbingan Teknis Penulisan Skripsi. Yogyakarta: Liberty.

Djinarto, B. (2000). Banking Asset Liability Management: Perencanaan, Strategi, Pengawasan dan Pengelolaan Dana. Jakarta: Gramedia Pustaka Utama.

Hammad, N. (1995). Mu'jam Al-Mushtholahat Al-Iqtishodiyah fi Lughotil Fuqaha'. Riyadh: AdDar Al-Ilmiyah lil Kutub Al-Islamy.

Haris, T. M. (2019, Februari 20). Akad Murabahah. (M. Winario, Interviewer)

Kebudayaan, K. P. (2020, April). KBBI Daring, Kamus Besar Bahasa Indonesia. Retrieved July 05, 2020, from KBBI Kemdikbud: https://kbbi.kemdikbud.go.id/

Kuwait, K. W. (2006). Al-Mausu'ah Al-Fiqhiyah Al-Kuwaitiyah. Kuwait: Kementrian Wakaf dan Urusan Islam Kuwait.

Manzhur, I. (2005). Lisanul Arab. Beirut: Darul Kutub Al-Ilmiyah.

Muhammad. (2005). Manajemen Bank Syariah. Yogyakarta: UPP AMPYKPN.

Purwanto, P. (2019). MENINGKATKAN PROFITABILITAS BANK SYARIAH MELALUI PEMBIAYAAN SEKTOR USAHA MIKRO, KECIL, DAN MENENGAH. Indonesian Interdisciplinary Journal of Sharia Economics (IIJSE), 1(2), 7-15. https://doi.org/10.31538/iijse.v1i2.178.

Qudamah, I. (2005). Al-Mughny. Kairo: Darul Hadits.

Septyanun, N., Dimyati, K., Setiaji, B., \& Basri, M. (2019). The Resurgence of Islamic Populist: Purification Understanding of Usury Banking in X-Banker Community-Indonesia. Journal of Advanced Research in Dynamical and Control Systems, 2760-2769.

Septyanun, N., Haq, H. S., Dimyati, K., \& Setiaji, B. (2018). Norm Characteristics Of Islamic Banking In Indonesia On Murabahah Instrument Towards Beyond Banking. Jurnal IUS Kajian Hukum dan Keadilan, 352-361.

Sudarsono, H. (2004). Bank dan Lembaga Keuangan Syariah Deskripsi dan Ilustrasi. Yogyakarta: Ekonisia. 
Sugiyono. (2012). Statistika Untuk Penelitian. Bandung: Alfabeta.

Sutedi, A. (2009). Perbankan Syariah: Tinjauan Dan Beberapa Segi Hukum. Jakarta: Ghalia Indonesia.

Thahmaz, A. H. (2001). Al-Fiqhul Hanafy fi Tsaubihil Jadid. Damaskus: Darul Qalam.

Warde, I. (2009). Islamic Finance Keuangan Islam dalam Perekonomian Global. Yogyakarta: Pustaka Pelajar. 